AGRO EKONOMI, Vol 29, No 1, Juni 2018, Hal.1-17

DOI : http://doi.org/10.22146/ae.29839

ISSN 0215-8787 (print), ISSN 2541-1616 (online)

Tersedia online di https://jurnal.ugm.ac.id/jae/

\title{
TECHNICAL EFFICENCY OF SOYBEAN IN PANDEGLANG REGENCY
}

\section{Efisiensi Teknis Kedelai Di Kabupaten Pandeglang}

\author{
Nivo Ardiansyah ${ }^{1}$, Slamet Hartono ${ }^{2}$, Any Suryantini ${ }^{3}$ \\ ${ }^{1}$ Master Student of Agricultural Economics, Faculty of Agriculture, Universitas Gadjah \\ Mada \\ ${ }^{2,3}$ Faculty of Agriculture, Universitas Gadjah Mada \\ Jl. Flora, Bulaksumur, Kec.Depok, Kabupaten Sleman, \\ Daerah Istimewa Yogyakarta 55281 \\ nivoardi@gmail.com
}

Diterima tanggal : 2 November 2017 ; Disetujui tanggal : 21 Maret 2018

\begin{abstract}
Pandeglang district is the largest soybean producer region in Banten province. Since the last four years, Pandeglang Regency has decreased land area and production. However, the amount of soybean productivity has increased. The ability of farmers to manage and allocate various inputs used in soybean farming affects the production and productivity of soybean and can give an idea of the level of efficiency achieved by farmers. So it is necessary to research whether the application or use of inputs in the process of soybean production has been at technically efficient level or not. Based on these conditions, in this study aims to: know the level of technical efficiency in soybean farming in Pandeglang regency. The basic method used in this research is descriptive method and the location of research is determined intentionally or purposive sampling. Sample selection for soybean farmer respondents was done by simple random sampling method of 77 soybean farmers. The result of the research shows that production factors that significantly affecting soybean production in Pandeglang are wide, fertilizer and insecticide. The average value of farmers' technical efficiency is 0.864. This figure indicates that the average farmers of respondents have reached technical efficiency in soybean production in the research area. the technical efficiency value of the stochastic function with the lowest value 0.6314 and the highest value 0.9599 . Factors affecting technical inefficiency are age and training. However, these factors have a positive effect, meaning that both increase the level of technical inefficiency of soybean farming.
\end{abstract}

Keywords: Pandeglang, soybean, technical efficiency, technical inefficiency

\section{INTISARI}

Kabupaten pandeglang adalah wilayah penghasil kedelai terbesar di Provinsi Banten. Sejak kurun waktu empat tahun terakhir Kabupaten Pandeglang mengalami penurunan luas lahan dan produksi. Namun, jumlah produktivitas kedelai mengalami kenaikan. Kemampuan petani dalam mengelola dan mengalokasikan berbagai input yang digunakan dalam usahatani kedelai berpengaruh terhadap produksi dan produktivitas kedelai serta dapat memberikan gambaran mengenai tingkat efisiensi yang dicapai oleh petani. Sehingga perlu adanya penelitian apakah penerapan atau penggunaan input dalam proses produksi kedelai sudah pada tingkat efisien secara teknis atau belum. Berdasarkan keadaan tersebut maka dalam 
penelitian ini bertujuan untuk: mengetahui tingkat efisiensi teknis pada usaha tani kedelai di Kabupaten Pandeglang. Metode dasar yang digunakan dalam penelitian ini adalah metode deskriptif dan lokasi penelitian ditentukan secara sengaja atau purposive sampling. Pemilihan sampel untuk responden petani kedelai dilakukan dengan metode simple random sampling sebanyak 77 petani kedelai. Hasil penelitian menunjukkan faktor-faktor produksi yang berpengaruh signifikan terhadap produksi kedelai di Pandeglang adalah luas, pupuk dan insektisida. Nilai rata-rata efisiensi teknis petani responden adalah sebesar 0,864. Angka ini menunjukkan bahwa rata-rata petani responden sudah mencapai efisiensi teknis dalam produksi kedelai di daerah penelitian. nilai efisiensi teknis dari fungsi stochastic dengan nilai terendah 0.6314 dan nilai tertinggi 0.9599. Faktor yang mempengaruhi inefisiensi teknis adalah umur dan pelatihan. Namun, faktor tersebut berpengaruh positif artinya bahwa keduanya meningkatkan tingkat inefisiensi teknis usaha tani kedelai

Kata kunci: efisiensi teknis, inefisiensi teknis, kedelai, pandeglang

\section{INTRODUCTION}

Soybean is a food plant in the form of shrubs that grows upright. The soybean plant can grow in every type of soil with decent soil drainage and aeration. In poor soil nutrient condition (barren), soybean could still grow well if it is stimulated with organic fertilizer, manure, and calcification.

Most of the soybean plants in Indonesia are cultivated in farming/ agriculture land. It happens because the soybean plant is very sensitive to water dehydration. Banten Province is one of the soybean producers in Indonesia. With the amount of production that is not overwhelming the other products from the other regions, in fact, Banten Province experiences the same issue faced by the entire Indonesian areas such as the decreasing number of yield land area. In the last five years, the yield areas of Banten Province have been very fluctuating which is followed by the decreased production of soybean (Central Agency on Statistic, 2016).
Production and productivity cannot only be increased by adoption and area expansion but also by enhancing the efficiency level of farmers to attain the maximum possible level of output from inputs at the disposal of the farmers and available technology. This last option requires identifying the level of efficiency and factors influencing inefficiencies (Tiruneh \& Geta, 2016).

In the presence of technical inefficiencies, farmers can increase their production levels without the need to increase the use of inputs that are usually scarce, or to adopt new technologies or practices. Bakhsh, et al, (2014) express that there are the ways to enhance the production, including extending the land/ agricultural area, developing and adopting the state of art technology as well as utilizing the available resources efficiently. In fact, there are more agricultural lands converted into settlement area which is 
caused by the population growth. In that order, the possible implement table solution is to adopt the advanced technology or utilizing the resources efficiently.

The efficient activity in agricultural business is one of the strategic steps in anticipating the lack of area or input reduction but able to produce the optimum production result (output) instead. The efficiency in agricultural business aims to enhance the utilization of agriculture resources through repairing effort and to increase the production result. Thus, it can be a more productive agricultural business.

Banten Province is a buffer area to fulfill the soybean demand in Indonesia. The soybean commodity in Banten Province is mostly cultivated in Pandeglang Regency. According to the 2016 statistical data of Banten Regency produced by Central Statistical Bureau, Pandeglang Regency produces about 10,332 tons of soybeans with 6,150 hectare area. Pandeglang Regency is the supplier of soybean need in Banten Province. Based on the data of Banten in Figure 2016 issued by Statistic Indonesia. Pandeglang Regency owns 10,332 tons production value with 6,150 harvested area and 16.80 tons/ha productivity. In four years period, the harvested areas of Banten Province have been very fluctuating which is followed by the decreased production of soybean.

During the last four years, the harvested area and soybean production in
Pandeglang Regency have been decreasing, however the soybean productivity is on the increasing trend in every year, in that case, the research regarding the implementation or the input utilization in soybean production process is required to analyze if it has been technically efficient or not. The analysis towards the productivity issue is actually the analysis towards the technical efficiency issue because the scale of productivity shows the scale of output that can be produced per certain input unit. In the soybean agricultural business, the technical efficiency rate is influenced by the combination of inputs utilization conducted by a farmer in the soybean production process.

The farmers' ability in managing and allocating various input utilized in soybean agricultural business affects the soybean production and productivity as well as describing the efficiency level that could be achieved by the farmers. Theoretically, the productivity enhancement is conducted by technology transformation, technical efficiency (TE), and economic scale (ES). To increase productivity, farmers face with a problem of the use of capital and appropriate technologies. To overcome this problem, selection of technology, combination usage of capital such seeds, fertilizers, medicines and the skilled labor will be basis for making appropriate decisions (Yekti et al, 2017). The soybean farmers in Pandeglang Regency have 
a tendency to plant the soybean on the third harvesting season after the paddy. According to the explanation above, the main aim of this research is to discover the technical efficiency rate of soybean agricultural business in Pandeglang Regency.

\section{METHODS}

The location of this research was conducted by purposive sampling, the research area was determined purposively with certain consideration. The location of the study was determined based on the sub-district with the largest amount of harvest and production in Pandeglang Regency, so the research was conducted in Panimbang Subdistrict. Method of respondents sampling was done by Random Sampling. The sample was determined by 77 respondents in Panimbang Subdistrict. The data used was a primary data of 2015.

\section{Production function method}

The model used to describe the relationship between soybean production and its independent variable in this research is production function method with a stochastic frontier approach by assuming the Cobb Douglas production function. Cobb Douglas production function is transformed into a natural linear logarithm, therefore, the production of soybean agricultural business in Panimbang District, Pandeglang Regency can be formulated below.

$$
\begin{aligned}
\operatorname{Ln} Y= & \alpha_{0}+\alpha_{1} \ln \mathrm{Xland}+\alpha_{2} \ln \mathrm{Xsds}+\alpha_{3} \\
& \ln \mathrm{Xfert}+\alpha_{4} \ln \mathrm{Xins}+\alpha_{5} \ln \mathrm{Xpoc}+ \\
& \alpha_{6} \ln \mathrm{XLb}+e \\
Y= & \text { Soybean production }(\mathrm{Kg}) \\
\mathrm{Xland}= & \text { Land area (ha) } \\
\mathrm{Xsds}= & \text { The number of soybean seeds } \\
& (\text { seed } / \mathrm{Ha}) \\
\mathrm{Xfert}= & \text { The amount of tsp fertilizer } \\
& (\mathrm{Kg} / \mathrm{Ha}) \\
\mathrm{Xins}= & \text { The amount of insecticide (Lt/ } \\
& \text { Ha) } \\
\mathrm{Xpoc}= & \text { The amount of organic liquid } \\
& \text { fertilizer (Lt/Ha) } \\
\mathrm{XLb}= & \text { The number of labors (Man days) } \\
\mathrm{e} \quad & \text { Error (disturbance term) }
\end{aligned}
$$

\section{Efficiency test}

\section{Technical efficiency}

The technical efficiency value can be discovered from the data processing result by utilizing the Frontier. The justifications of efficiency level are if the technical efficiency value is equal to one, thus the input utilization in soybean agricultural business is already efficient. While if the technical efficiency value is unequal to one, thus the input utilization in soybean agricultural business has not been efficient.

In order to acquire the TE (technical efficiency) from the soybean agricultural business, the calculation below is conducted: $T E=\frac{Y_{i}}{\hat{Y}_{i}}=\frac{E\left(Y_{i} \mid U_{i}, X_{i}\right)}{E\left(Y_{t} \mid U_{i}=0, X_{i}\right)}=E\left[\frac{\exp \left(-U_{i}\right)}{\varepsilon_{i}}\right]$

The output oriented measure of TE can be expressed as the ratio of observed 
output to the corresponding stochastic frontier output, a measure that takes a value between 0 and 1.(Guesmi, et. al, 2012). If the TE value is closer/approaching to 1 , the agricultural business can be perceived as technically more efficient and if the TE value is closer to zero thus the agricultural business can be perceived as technically more inefficient. The frontier production function is explained below:

$\begin{aligned} \operatorname{Ln} Y= & \alpha_{0}+\alpha_{1} \ln \mathrm{Xland}+\alpha_{2} \ln \mathrm{Xsds}+\alpha_{3} \\ & \ln \mathrm{Xfert}+\alpha_{4} \ln \mathrm{Xins}+\alpha_{5} \ln \mathrm{Xpoc}+ \\ & \alpha_{6} \ln \mathrm{XLb}+\left(V_{i}-U_{i}\right) \\ Y= & \text { Soybean production }(\mathrm{Kg}) \\ \text { Xland }= & \text { Land area (ha) } \\ \text { Xsds }= & \text { The number of soybean seeds } \\ & (\text { seed } / \mathrm{Ha}) \\ \text { Xfert }= & \text { The amount of tsp fertilizer } \\ & (\mathrm{Kg} / \mathrm{Ha}) \\ \text { Xins }= & \text { The amount of insecticide }(\mathrm{Lt} /\end{aligned}$ $\mathrm{Ha})$

Xpoc $=$ The amount of organic liquid fertilizer $(\mathrm{Lt} / \mathrm{Ha})$

$\mathrm{XLb}=$ The number of labors (Man days)

$\mathrm{Vi}=$ The error caused by random selection (the error caused by farmers incapability to control)

$\mathrm{Ui}=$ The effect from the occurrence of technical efficiency (the error that can be controlled by farmers)

The inability of the farmer to attain the maximum output is known as inefficiency. There are factors under the control of farmers. Failure to manage resources explains the inefficiency among farmers since farmer is operating under the same technology (Abiola et al, 2014). The main factors included in the inefficiency production model of soybean agricultural business are the farmers' age, agricultural business experience, education level, and participation in farming workshop. Those factors will massively influenced by the agriculture business productivity rate.

In order to observe the influence capability of those factors, the determination factor analysis of production inefficiency rate by using econometric model will be conducted as what shown below.

$U i=\delta_{0}+\delta_{1} Z_{1}+\delta_{2} Z_{2}+\delta_{3} Z_{3}+\delta_{4} Z_{4}$

$\mathrm{Ui}=$ The value of technical inefficiency

$\delta_{\mathrm{o}}=$ Constanta

$\mathrm{Z}_{1}=$ Farmers' age

$Z_{2}=$ Soybean agricultural business experience

$\mathrm{Z}_{3}=$ Education level

$Z_{4}=$ Participation in workshop/training

Ui is the information regarding the production inefficiency achieved by the $i$-farmer, $Z_{1}-Z_{4}$ are the farmers' age, business experience, participation in farming workshop, and the number of dependent family which is all arranged in consecutive manner. The parameter from the model of frontier production function and the Ui explained above are 
simultaneously estimated by Maximum Likelihood Estimation (MLE) method by using frontier 4.1 computation program.

\section{RESULT AND DISCUSSION}

\section{Farmers characteristic}

Farmers characteristic based on age category

The farmers' age is one of the factors which highly related to the working capability in conducting the agricultural business activity. The older farmers usually tend to be very conservative or less responsive towards the transformation of technological innovation. The younger farmers are eagerly passionate towards the new thing and tend to be responsive towards a transformation.

The farmers' age structure in research location shows relatively heterogeneous condition (Table 1). The age of soybean farmers that mostly categorized in productive age (21-60 years old) or about $86 \%$ with the average age is 47 years old. At that age, farmers are still able to run the farming activities optimally so that it can affect the level of production that can be achieved. Unlike farmers who already have age above 60 are classified as unproductive, at this time the ability of farmers in farming activities will experience a decrease in terms of energy.

Table 1. The Farmers Characteristic based on Age Category

\begin{tabular}{|c|c|c|}
\hline Age of farmers & Quantity (Person) & Percentage $(\%)$ \\
\hline$\leq 20$ & 0 & $0 \%$ \\
\hline $21-30$ & 4 & $5 \%$ \\
\hline $31-40$ & 25 & $32 \%$ \\
\hline $41-50$ & 18 & $23 \%$ \\
\hline $51-60$ & 19 & $25 \%$ \\
\hline$>60$ & 11 & $14 \%$ \\
\hline & 77 & $100 \%$ \\
\hline
\end{tabular}

Source: Primary Data Analysis, 2017

Farmers characteristic based on experience

Table 2. Farmers Characteristic based on experience

\begin{tabular}{ccc}
\hline Experience (Year) & Quantity (person) & Percentage (\%) \\
\hline $1-3$ & 40 & $52 \%$ \\
$4-6$ & 27 & $35 \%$ \\
$>6$ & 10 & $15 \%$ \\
\hline Total & 77 & $100 \%$ \\
\hline
\end{tabular}

Source: Primary Data Analysis, 2017 
Experience is a collection of knowledge of a human being that is acquired from their sense utilization which later is arranged into patterned shape. Someone's experience in agricultural business has an influence towards the response in accepting the new technology and innovation. The farmer with more experience will be easier in implementing the input or suggestion from the agriculture facilitator in parallel with the implementation of an appropriate technology.

Experience is one the determinant factors towards the success of a certain agricultural business. Farmers who have been running agricultural business in a long period of time will own a tendency to know more regarding the good and bad; the suitable and unsuitable agricultural business that is being conducted and willingly adopt the technology used in the run of agricultural business. The experiences of soybean farmers are represented by how long they run soybean agricultural business (Table 2).

Farmers' experience in soybean farming in the research area is classified as new, average farmer experience is 3.6 years. Extension workers in regular research areas hold training each year near the soybean growing period to provide good cultivation techniques. in table 3 , the farmers' experience is divided into three categories: new farmers (1-3 years), moderate (4-6 years) and longer (more than
6 years). Most of the farmers in the research area have at most 1-3 years experience with 40 farmers.

\section{Farmers characteristic based on education}

Education is highly important either in a formal or non-formal form with the aim to alter the attitude, behavior, and perception. Through education, someone will be able to acquire new innovation of information and technology, thus it influences the decision-making standard. Formal education followed by farmers will affect the knowledge and insight of farmers. The higher education conceived by farmers would make them easier to understand and accept the new innovation delivered to them. In Table 3, various main/ core descriptions regarding the soybean farmers' education are presented.

According to the data in Table 3, it is discovered that most respondent farmers only have elementary school

Table 3. Farmers Characteristic Based on Education

\begin{tabular}{lcc}
\hline \multicolumn{1}{c}{ Education } & $\begin{array}{c}\text { Quantity } \\
\text { (Person) }\end{array}$ & Percentage \\
\hline $\begin{array}{l}\text { Not graduate } \\
\text { Elementary }\end{array}$ & 0 & $0 \%$ \\
$\begin{array}{l}\text { School } \\
\text { Junior High }\end{array}$ & 66 & $86 \%$ \\
$\begin{array}{l}\text { School } \\
\text { Senior High }\end{array}$ & 8 & $10 \%$ \\
$\begin{array}{l}\text { School } \\
\text { Higher }\end{array}$ & 3 & $4 \%$ \\
Education & 0 & $0 \%$ \\
\hline Total & 77 & $100 \%$ \\
\hline
\end{tabular}

Source: Primary Data Analysis, 2017 
education which is about $66 \%$ of them.

The higher the level of education of farmer, the easier farmers adopt soybean cultivation techniques. Conversely, if the low level of education allows the occurrence of obstacles in the absorption of integrated cultivation techniques by farmers, making it difficult for farmers to apply good cultivation techniques.

Farmers' characteristic based on workshop/training

Table 4. Farmers Characteristic Based on Workshop/training

\begin{tabular}{lcc}
\hline Workshop & $\begin{array}{c}\text { Quantity } \\
\text { (person) }\end{array}$ & $\begin{array}{c}\text { Percentage } \\
(\%)\end{array}$ \\
\hline Never & & \\
participated & 13 & $17 \%$ \\
$1-3$ & 53 & $69 \%$ \\
$4-6$ & 10 & $13 \%$ \\
$>6$ & 1 & $1 \%$ \\
\hline Total & 77 & $100 \%$ \\
\hline
\end{tabular}

Source: Primary Data Analysis, 2017

The agricultural business workshop in the research location aims to develop farmers; skill in soybean agricultural business thus they would produce the expected soybean product. The soybean cultivation in the research location has been cultivated since 9 years ago. This condition requires the role of facilitators to support the farmers in the soybean production activity through the training/workshop for soybean agricultural business. The workshop participated by farmers includes the soybean cultivation technique/method and the risk management for agricultural business. The respondent farmers in the research location have participated in the activity for two to four times in average.

\section{The Statistical Description of Input and Output}

According to the production function that is being observed, the inputs used in the process of soybean agricultural business are land area (ha), seed $(\mathrm{kg})$, tsp fertilizer $(\mathrm{kg})$, insecticide (liter), poc (organic liquid fertilizer in liter) and labor.

The agricultural service Pandeglang Regency recommends the use of soybean cultivation input through local agricultural extension agents. The recommendation for production input utilization per Ha from the local facilitating is $25 \mathrm{~kg}$ of clean-use, $150 \mathrm{~kg}$ of tsp fertilizer, 2 liters of insecticide and 3 liters of poc (organic liquid fertilizer). There are some differences from the use of recommended inputs with the use of inputs used by farmers. Differences could be found in the use of seeds, tsp fertilizers and insecticides that exceed the recommended use for each hectare. In addition, the use of poc is not in accordance with the suggestion of input from the local extension agent. The average production and input utilization can be seen in Table 5 . 
Table 5. The average production input utilization per ha and the average production of soybean

\begin{tabular}{lr}
\hline Variable Input - output & \multicolumn{1}{c}{ Average } \\
\hline Production & $1500.04 \mathrm{Kg} / \mathrm{Ha}$ \\
Land area & $1.4013 \mathrm{Ha}$ \\
Seed & $28.8 \mathrm{Kg} / \mathrm{Ha}$ \\
Tsp Fertilizer & $117.9 \mathrm{Kg} / \mathrm{Ha}$ \\
Insecticide & $2.94 \mathrm{~L} / \mathrm{Ha}$ \\
POC & $2.21 \mathrm{~L} / \mathrm{Ha}$ \\
Labors & $48 \mathrm{Man}$ days \\
\hline
\end{tabular}

Source: Primary Data Analysis, 2017

\section{The Analysis of Technical Efficiency Rate \\ Regression Function}

The estimated result of the production function through the production function model of stochastic frontier shows that the production function is manifested decently (best fit) which describes the farmers' behavior during the production process. The estimated result of Cobb-Douglas production function by using OLS method is presented in Table 6 .

Land area has a positive coefficient value about 0.8199378 . This value shows that every $1 \%$ of addition to a land area will increase the soybean production to about 0.8199 percent. The land area variable conceives the highest elasticity (0.8199) compares to the other variables. Therefore, the addition to the land area can be used as an option to enhance the soybean production in the research location.

The common seed planted in the research location is the anjasmoro seed variety. The utilization of soybean seed in the research location is assumed to have been overused on every hectare. This condition can be explained from the estimated result which shows that the seed variable acquires negative coefficient value about -0.0471 and not significantly influence the soybean production.

The tsp fertilizer variable is significantly affecting at $1 \% \alpha$ and has a positive coefficient value about 0.2598 . It means that every $1 \%$ addition of tsp fertilizer input will increase the soybean production as much as the value of tsp fertilizer input elasticity, which is about $0.2598 \%$. This result correlates positively to the actual field condition that shows that the tsp fertilizer utilization is highly required due to its function as an extra nutrient for soil and repair the soil physical structure. This study is in agreement with the works of Ibrahim, (2014) that tsp fertilizer significantly increases the output.

Insecticide is one of pesticide types which according to the target organism used to kill insects. The utilization of insecticide in the analysis at the research location resulted in -0.0505 negative coefficient values and significantly influences at $10 \% \alpha$ level which means that the $1 \%$ addition of insecticide will decrease the soybean production to about -0.0505 percent. According to this elasticity value, it is assumed that the 
insecticide utilization is overused. This can be explained from the amount of insecticides used by farmers proved to be used excessively. The average number of insecticides used by farmers is $2.94 \mathrm{~L}$, while the amount recommended by the local extension agent is $2 \mathrm{~L}$ per hectare.

The poc (organic liquid fertilizer in liter) variable does not significantly have influence and has positive coefficient value towards the soybean production at the research location. The smallest elasticity value between the other positive variables is poc (organic liquid fertilizer in liter) however, variable poc (organic liquid fertilizer in liter) is not significant to soybean production.

The estimated result in Table 6 shows that the labor variable acquired
-0.0524 negative coefficient values but it is insignificant, means that the labor variable has no effect on soybean production.

The utilization of labor in the soybean agricultural business resulted in negative coefficient value which shows that in the research location; the utilization of labor is overextended. Thus the effort in reducing the work schedule in the soybean agricultural business at the research location is required.

The estimation of frontier production function

The second phase is the estimation of production function using Maximum Likelihood Estimation (MLE) method. According to the estimated result in Table 7 , it can be seen that the likelihood log value

Table 6. The Estimation of Cobb-Douglass production function by using OLS method

\begin{tabular}{lrrrr}
\hline Variable & \multicolumn{1}{c}{ Coefficient } & & Std. Error & \multicolumn{1}{c}{ t-ratio } \\
\hline Constanta & -1.3832642 & $\mathrm{~ns}$ & 0.809587 & -1.7086040 \\
Land Area $\left(\mathrm{X}_{1}\right)$ & 0.8199378 & $* * *$ & 0.136317 & 6.0149212 \\
Seed $\left(\mathrm{X}_{2}\right)$ & -0.0471510 & $\mathrm{~ns}$ & 0.088968 & -0.5299784 \\
Tsp Fertilizer $\left(\mathrm{X}_{3}\right)$ & 0.2598981 & $* * *$ & 0.096510 & 2.6929602 \\
insecticide $\left(\mathrm{X}_{4}\right)$ & -0.0505973 & $*$ & 0.035976 & -1.4064235 \\
Poc $\left(\mathrm{X}_{5}\right)$ & 0.0422339 & $\mathrm{~ns}$ & 0.055719 & 0.7579836 \\
Labor $\left(\mathrm{X}_{6}\right)$ & -0.0524826 & $\mathrm{~ns}$ & 0.101090 & -0.5191688 \\
\hline R-Square & 0.87401 & & & \\
\hline Adj R-Square & 0.86321 & & \\
\hline f-statistic & 80.93300 & & \\
\hline f-prob & 0.00000 & &
\end{tabular}

Source: Primary Data Analysis, 2017

Note : $*=$ Significantly influence at $10 \%$

$* * \quad=$ Significantly influence at $5 \%$

$* * * \quad=$ Significantly influence at $1 \%$

ns $\quad=$ Not significantly influence

F-tab $=$ significantly influence at $1 \%$ 
resulted from the utilization of Maximum Likelihood Estimation (MLE) method (-41.26) is bigger than the likelihood log value resulted from the utilization of OLS method (-44.74) which means that it's a decent result and in accordance with the actual condition.

Table 7 describes the variant/sigmasquare and $\mathrm{Y}$ parameter of the technical inefficiency effect model of stochastic frontier production function of the soybean agricultural business with farmers as the respondent. The major advantage of the stochastic frontier production function model is the introduction of disturbance term representing the noise, measurement error and exogenous factors beyond the control of the production unit in addition to the inefficiency component (Shehu, et al, 2010).

The variant value shows the distribution of inefficiency error term (ui), if the value is small; it indicates that (ui) is normally distributed. The inefficiency influence in the stochastic frontier model is shown by the sigma-square and gamma values. The sigma-squared value is the total variety distributed by the inefficiency and external effects, while gamma value is the ratio of inefficiency effect variety towards total production variety. The sigma-square value is 0.0257 which is categorized as a very small value that significantly influences at $1 \% \alpha$ level and normally distributed due to its small value or approaching to zero. Thus, it can be concluded that the soybean production varieties contributed by the inefficiency and external effect have the significant/ actual variety.

The gamma value is the contribution from technical efficiency in the total residual effect. The gamma value that approaching to $1(0.636790)$ shows that the error term results from the inefficiency effect and the rest is from the noise (weather, climate, pest, etc). If the value of gamma value is close to 1 , then the error is only derived from the inefficiency effect and if the value of number 0 then such as, climate, pests and diseases, etc. are not due to the inefficiency (Kibaara \& Kavoi, 2012). The approximate value of 00 implies much of the observed output variation of the frontier output caused by the stochastic random effect, whereas the value of $\gamma$ approaches one roughly states the variation of random output by the inefficiency or technical efficiency difference (Ogundari \& Ojo, 2008).

The value resulted from generalizedlikelihood (LR) of stochastic frontier production function is 6.97 which significantly influence at $2.5 \% \alpha$ level or the LR value is bigger than the Kodde and Palm value table at $2.5 \% \alpha$ level (6.483). This means that the stochastic frontier production function can explain the existence of technical efficiency and inefficiency of farmers during the production process. 
The estimated result in Table 7 shows that the variables that significantly influence the frontier are the land area, tsp fertilizer, and insecticide while the variables that have no significant influence towards the soybean production are seed, poc (organic liquid fertilizer in liter), and labor.

The frontier elasticity acquired from the land area variable was discovered having a significant influence towards the soybean production at $1 \%$ a level with 0.795619 value. This result shows that the $1 \%$ addition to a land area of soybean agricultural business will enhance $0.795619 \%$ of soybean production. This result is in line with the research of Febianti. et al, (2015) where the land area variable has the greater influence compared to other variables.

The average land area used by farmers in the research location is 1.4 ha with the widest land used is about $2.15 \mathrm{Ha}$ while the narrowest land area use is 0.5 ha. The tsp fertilizer variable has significant influence and 0.2750 positive coefficients which means that every $1 \%$ addition of tsp fertilizer variable could enhance $0.2750 \%$ of the soybean production the average utilization of tsp fertilizer used by farmers is $117.9 \mathrm{~kg} / \mathrm{ha}$.

Insecticide has negative coefficient which means that any addition of insecticide amount in soybean agricultural will decrease the number of soybean production. This condition is assumed as the result of the excess use of insecticide in the research location. The average utilization of insecticide by farmers is 2.9 liters/ha with 1-liter minimum value and 5-liter maximum value. According to the regression result in Table 6, it shows that

Table 7. The estimation of frontier production function

\begin{tabular}{lcrrr}
\hline Variable & Parameter & \multicolumn{1}{c}{ Coefficient } & & \multicolumn{1}{c}{-ratio } \\
\hline Constanta & $\alpha_{0}$ & -1.020500 & ns & -1.207514 \\
Land area $\left(\mathrm{X}_{1}\right)$ & $\alpha_{1}$ & 0.795619 & $* * *$ & 5.778378 \\
Seed $\left(\mathrm{X}_{2}\right)$ & $\alpha_{2}$ & -0.054152 & $\mathrm{~ns}$ & -0.616315 \\
Tsp Fertilizer $\left(\mathrm{X}_{3}\right)$ & $\alpha_{3}$ & 0.275048 & $* * *$ & 2.985054 \\
Insecticide $\left(\mathrm{X}_{4}\right)$ & $\alpha_{4}$ & -0.046392 & $*$ & -1.332532 \\
Poc $\left(\mathrm{X}_{6}\right)$ & $\alpha_{5}$ & 0.036569 & $\mathrm{Ns}$ & 0.686026 \\
Labor $\left(\mathrm{X}_{7}\right)$ & $\alpha_{6}$ & -0.060152 & Ns & -0.581387 \\
Sigma-squared $\left(\Sigma^{2}\right)$ & & 0.025783 & $* *$ & 2.121642 \\
Gamma $(\gamma)$ & & 0.636790 & $* *$ & 1.949400 \\
Log-likelihood function OLS & & & -44.74 & \\
Log-likelihood function MLE & & & -41.26 & \\
LR Test of the one $=$ sided error & & & & \\
\hline
\end{tabular}

Source: Primary Data Analysis, 2017

Note : $* \quad=$ Significantly influence at $10 \%$

$* * \quad=$ Significantly influence at $5 \% \alpha$

$* * * \quad=$ Significantly influence at $1 \% \alpha$

ns $\quad=$ Not significantly influence 
the farmers are still rational in adding the inputs utilization of land area, tsp fertilizer, and reducing the insecticide utilization to enhance their production.

The variables of seed, poc (organic liquid fertilizer in liter), and labor do not significantly influence the frontier. This condition is assumed as the result of the excess use of production inputs beyond the applicable general standard.

\section{Technical efficiency analysis}

The technical efficiency rate of soybean agricultural business in the research location is presented in Table 8. According to the analysis results of the individual technical efficiency of the respondents, it is found that the average index value of technical efficient achieved by the respondent farmers in the research location is 0.86418 . The index value of the technical efficiency is categorized as efficient if the value is bigger than 0.7 (Kumbakar dan Lovell 2000, Nwaru, et al, 2011). The 0.86418 value shows that the average respondent farmers have been achieved technical efficiency in soybean production in the research location. The technical efficiency index in Table 8 shows that the average value of technical efficiency from the stochastic frontier function is 0.86418 with 0.6314 as the lowest value and 0.9599 as the highest value acquired. The average value of technical efficiency in that model shows the average respondent farmers that have acquired high result. Thus, it is approaching the maximum result and technically become the most efficient. In a short time period, the average soybean farmers in the research location are only having a chance to enhance their production at 9.971 percent rate (1-(0.86418/0.9599)).

By utilizing the 0.7 efficiency index criteria as the efficiency limit, the entire farmers in the research location are categorized as efficient people. The average respondent farmers in the research location have been technically efficient farmers, thus those farmers are not required to add

Table 8. The Frequency Distribution of Technical Efficiency

\begin{tabular}{ccc}
\hline Index Distribution & The number of farmers & Percentage \\
\hline $0.51-0.60$ & 0 & 0 \\
$0.61-0.70$ & 1 & 1 \\
$0.71-0.80$ & 14 & 18 \\
$0.81-0.90$ & 34 & 44 \\
$0.91-1.00$ & 28 & 36 \\
Total & 77 & 100 \\
\hline Average & 0.8641 & \\
Minimum & 0.6314 & \\
Maximum & 0.9599 & \\
\hline
\end{tabular}

Source: Primary Data Analysis, 2017 
the production inputs that significantly influence towards soybean production However, the farmers still have to be concerned towards the factors that influence the technical efficiency as the cause of inefficiency occurrence.

The Sources of The Technical Efficiency for Soybean Agricultural Business

The LR value that has significant influence means that every determinant variable in the inefficiency effect model has an influence towards the inefficiency rate during the soybean production process. The estimated result by utilizing the inefficient effect model of production function of stochastic frontier can be seen in Table 9.

Based on Table 9 above, the variables that have a negative coefficient sign is the agricultural business experience and the number of the family dependent. While the variables that have positive coefficients are age, education, and training/workshop. The value of the coefficient can affect the technical efficiency of soybean agricultural business.

The farmers' age variable is known to have a positive of 0.004927 and is significant at a $5 \%$. This indicates that the increasing age of farmers will decrease the efficiency rate of the business or increase the level of technical inefficiency. This condition occurs because the performance of the older farmers will obviously lower than the young farmers. This condition also explains that the increasing age of farmers, the ability to work, skills, and physical strength will decrease as well. Low working ability will inhibit the efforts of improvements in cultivation activities. This is in line with some previous studies such as (Ajao, Ogunniyi, \& Adepoju, 2012). The older the farmers, the more increase the inefficiency. This is because over the time, the ability to work and the desire to bear the risk of declining. As a result have an impact on increasing inefficiency.

Training/workshop is a process conducted by a person to acquire a certain ability in achieving a particular goal. Training for farmers is generally prepared by the facilitators in order for the farmers to adopt an action or to adapt an agricultural technology. Thus, that the ability and skills of farmers in the agricultural business will increase. Therefore, soybean production can be improved or enhanced.

The training / workshop variables have a positive value of 0.036042 and have a significant influence on the level of $10 \% \alpha$, meaning that every training activity followed by farmers will increase the effect of technical inefficiency by 0.036042 percent. This result shows that the training variables can decrease the level of technical efficiency. Training is a form of non-formal education acquired by the farmers. From Table 9, it is discovered that if the training variables are improved, the inefficiency rate will increase. 
In general, training will enable farmers to acquire skills in an effort to enhance the production and efficiency rate or lower the level of inefficiency value. However, according to inefficiency test results in the research area, the training variables found to have the opposite effect.

Educated farmers are able to collect, understand and utilize information from the observations, research and experience compared to farmers with low education level.

The coefficient of education is insignificant with a value of 0.017947 with a positive sign, which means that the influence of education does not affect the technical inefficiency on soybean farming. This is in line with the previous research conducted by Barre (2012), who states that the educational background of

Table 9. The estimation towards the factors that influence the technical inefficiency

\begin{tabular}{lcc}
\hline Variable & Coefficient & t-ratio \\
\hline Age $\left(\mathrm{Z}_{1}\right)$ & $0.004927^{* *}$ & 2.126568 \\
$\begin{array}{l}\text { Agricultural } \\
\text { Business }\end{array}$ & $-0.059345^{\mathrm{Ns}}$ & -1.25546 \\
$\begin{array}{l}\text { Experience }\left(\mathrm{Z}_{2}\right) \\
\begin{array}{l}\text { Education }\left(\mathrm{Z}_{3}\right) \\
\text { Training/ }\end{array}\end{array}$ & $0.017947^{\mathrm{Ns}}$ & 0.206801 \\
workshop $\left(\mathrm{Z}_{4}\right)$ & $0.036042^{*}$ & 1.522620 \\
\hline
\end{tabular}

Source: Primary Data Analysis, 2017

Note: $*=$ Significantly influence at $10 \% \alpha$ level (1.293)

$* *=$ Significantly influence at $5 \%$ $\alpha$ level (1.666)

$* * *=$ Significantly influence at 1 $\% \alpha$ level (2.380)

$\mathrm{ns}=$ Not significantly influence farmers in the research area that on average are elementary school graduates and the lack of experience in soybean agricultural business could possibly indicate that the information provided by facilitators during the training/workshop activity is not decently understood by the farmers.

\section{CONCLUSION AND SUGGESTION Conclusion}

This research was conducted in 2015 to estimate the function of soybean production and the technical efficiency rate of soybean agricultural business in Pandeglang Regency. Soy farmers can be categorized as technically efficient if the efficiency value of farmers is above 0.77 . The average soybean farmers in Pandeglang Regency are technically efficient farmers (86.4 percent). The opportunities to improve the technical efficiency are still able to be conducted technically through revamping the influencing factors.

\section{Suggestion}

The policy implications that can be proposed in association to this research are: the efforts to enhance the productivity can be conducted by increasing the utilization inputs of land area, tsp fertilizer, and reduce the utilization of insecticides. Aside from that, reducing the number of seeds utilization and schedule an efficient working time are required. The inefficiency test results 
indicate that the training/workshop has an increased effect towards the inefficiency issue thus the improvement efforts in the implementation or the delivery of training materials are highly required. This effort is not aimed to reduce the training frequency in order to decrease the inefficiency but instead to review whether the training materials are possible to implement or not in order to maintain consistency of the production process. The consideration for incorporating other inefficiency source factors for further research is not covered in this research yet. These factors may include the status or form of land tenure, and the number of family dependent (the family members who are able to support the agricultural business process).

\section{REFERENCES}

Abiola, M. O., \& Daniel, I. (2014). Efficiency of Melon Production in Oredo and Egor Local Government Area of Edo State, Nigeria. International Journal of Agriculture Innovation and Research, 2(5), 732-738.

Ajao, A. O., Ogunniyi, L. T., \& Adepoju, A. A. (2012). Economic Efficiency of Soybean Production in OgoOluwa Local Government Area of Oyo State, Nigeria. American J Experiment Agr, 2(4), 667-679.
Bakhsh, K., Hassan, S., Kamran, M. A., \& Saeed, R. (2014). Determinants of Environmental Efficiency in Bitter Gourd Abstract : I. Introduction. Journal of Agricultural Sciences, 34(1), 167-176.

Barre, M. A. (2012). Measuring Technical Efficiency OfOnion (Allium cepa L.) Farms In Bangladesh. Bangladesh Journal of Agricultural Research, 37(march), 171-178.

Febianti. D.I, Jamhari. \& Haryanto, S. (2015). Efisiensi Usahatani Tebu di Kabupaten Purworejo. Agro Ekonomi, 26(june), 1.

Guesmi, B., Serra, T., Kallas, Z., \& Gil Roig, J. M. (2012). The productive efficiency of organic farming: the case of grape sector in Catalonia. Spanish Journal of Agricultural Research, 10(3), 552. https://doi. org/10.5424/sjar/2012103-462-11

Ibrahim, U. W. (2014). Technical Efficiency and its Determinants in Water Melon Production in Borno State, Nigeria. Journal of Economics and Sustainable Development, 5(27), 205-212.

Kibaara, B. W., \& Kavoi, M. M. (2012). Application of Stochastic Frontier Approach Model To Assess Technical 
Efficiency in Kenya'S Maize

Production. JAGST, 14(1), 3-20.

Nwaru, J. C., Okoye, B. C., \& Ndukwu, P. C. (2011). Measurements and Determinants of Production Efficiency among Small-Holder Sweet Potato (Ipomoea Batatas) Farmers in Imo State, Nigeria. European Journal of Scientific Research, 59(3), 307-317.

Ogundari, K., \& Ojo, S. O. (2008). An Examination of Technical, Economic and Allocative Efficiency of Small Farms : The Case Study of Cassava Farmers in Osun State of Nigeria. Central European Agriculture Journal, 7(3), 423-432.

Shehu, J., Iyortyer, J., Mshelia, S., \& Jongur, A. (2010). Determinants of yam production and technical efficiency among yam farmers in Benue State, Nigeria. Journal of the Scientific Society, 24(2), 143-148.

Tiruneh, W. G., \& Geta, E. (2016). Technical efficiency of smallholder wheat farmers: The case of Welmera district, Central Oromia, Ethiopia. Journal of Development and Agricultural Economics, 8(2), 39-51. https://doi. org/10.5897/JDAE2015.0660

Yekti, A., Darwanto, D. H., Jamhari, \& Hartono, S. (2017). Efisiensi Usahatani Melon Dan Perilaku Terhadap Risiko Petani Melon Lahan Pasir Dan Lahan Sawah Di Kabupaten Kulon Progo. Universitas Gadjah Mada. Retrieved from http:// etd.repository.ugm.ac.id/index. php?mod=penelitian_detail\&sub=P enelitianDetail\&act $=$ view \& typ $=\mathrm{ht}$ ml\&buku_id=127916\&obyek_id=4 